\title{
Challenges and Countermeasures on the Development of Private Commercial Banks: Taking China Minsheng Bank Corp as the Example
}

\author{
Yanhua Xu \\ Qingdao University of Technology, Shandong Qingdao, 266300, China.
}

Keywords: Minsheng Bank, Example, Private Commercial Banks, Challenges, Countermeasure.

\begin{abstract}
This paper analyzes the challenges and countermeasures on the development of the private commercial banks with the example of China Minsheng bank corp. Private banking problem is the focus of the theory discussed in recent years as private banks development theory problems for private banks plays an important role in guiding the practice. The establishment of private Banks can improve the efficiency of the China's financial and economic operation, but in the national utility function to enhance the efficiency of this at the expense of the loss of part of the country's financial control. With this basis, we take the China Minsheng bank corp as example to conduct the theoretical analysis that will be meaningful and somewhat meaningful.
\end{abstract}

\section{Introduction}

The private capital is an important component of the banking capital in our country. The China banking regulatory commission data show that by the end of 2015, the joint-stock commercial Banks and city commercial Banks in the total equity, private capital than accounted for $45 \%$ and $59 \%$, respectively; Rural folk capital in the overall structure of small and that medium-sized financial institutions accounted for $91 \%$, the rural cooperative financial institutions folk capital accounts for the $95 \%$ of the equity ownership structure. We can say, let the private capital into the financial sector, breaking the monopoly of the state-owned banks, that spoke for many years, but until recently the government attitude clear, especially the financial the ten countries that has over the years has been calling for private capital into the financial sector, especially banking industry had a breakthrough. This is a significant step in China's financial reform and based on the theoretical literature review, the developmental trend for the bank industry could be summarized as follows [1-3].

- Commercial, financial and competitive field and risk and speculative rather than competitive commercial and basic industrial fields. Thus require commercial banks to have hard budget constraints. To make the hardening budget constraint of commercial Banks, to satisfy the two conditions at the same time.

- Development of village banks is to alleviate small micro enterprise financing difficulties are urgently needed. To point out, by the way, "private bank" does not necessarily will mainly "to support small micro enterprise", that only tiny "private bank" main "support small micro enterprise".

- Private banks are in the market competition in the survival and development, and its operating mechanism to adapt to the market, often appear stronger vitality. Especially in the "off" and regulation under the condition of relatively strict, even more so.

Under this basis and to deal with the challenges mentioned, in this paper, we will conduct research on the development of private commercial banks while taking China Minsheng bank corp as example.

\section{The Proposed Methodology}

Commercial Banks Development. At present, China's commercial banks are actively through technology innovation, develop the ATM, telephone banking, the online banking, electronic banking system and credit management such as customer service centers, customer relationship management, risk management, and other management information system, and achieved some results. But due to 
the immature management practice experience, the operation risk of commercial banks in China was still in the stage of understanding, deepen, in risk management concept, idea, system and management tools with the international banking industry has very big disparity, operational risk of the Chinese commercial banks is still high. We firstly show the architecture in the figure one.

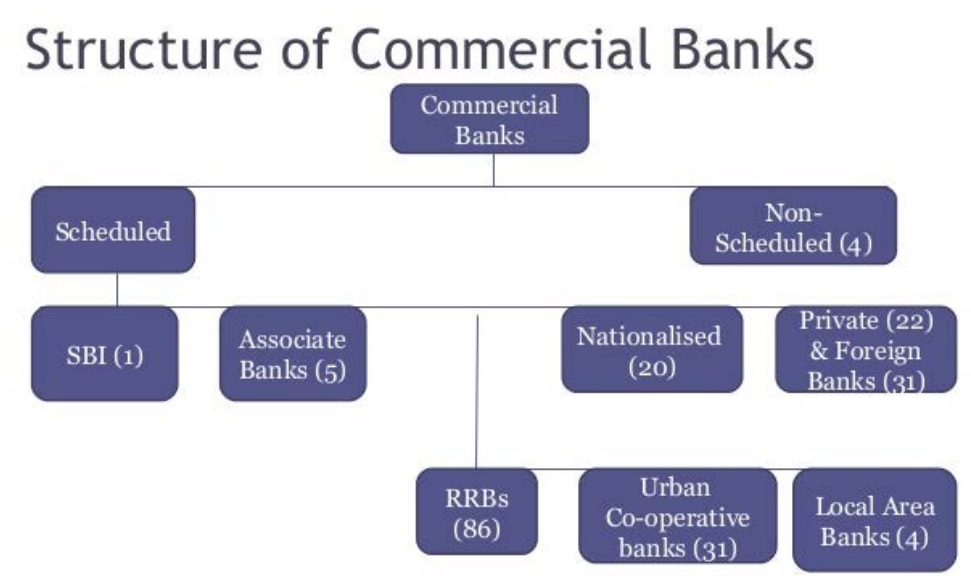

Fig. 1 The General Structure of the Commercial Banks

Although compared with the state-owned banks, the more reflected some of the characteristics of modern commercial banks however, at present it is not complete in the sense of modern commercial banks reflected from the following aspects. (1) Internationalization is actually one of the important contents of the socialist market economy, is the development of the market at a higher level, the internationalization of a commercial bank monopoly alone are not enough, to further promote that comprehensive internationalization, commercial Banks in the international competition mechanism in the banking business. (2) Because although some foreign Banks have entered China, but not after all to establish a stable, cannot be compared to domestic Banks, which also require commercial Banks to develop international business as soon as possible, to provide general foreign currency exchange, international settlement, exchange, foreign exchange loans supporting general local currency lending, consulting agency business, to adapt to needs of the development of economic internationalization.

Bank's Development Review. In recent years, the joint-stock commercial bank as an important part of the financial system in our country, in support of the national economy construction, promote the development of the financial system and improve the commercial bank risk management and the innovation ability that has played an important role. Under this reform logic, based on the external economic environment, policy environment, legal environment of effective support and bank itself in such aspects as institution, technology and culture of the innovation efforts, joint-stock commercial banks to achieve the leap development of the fast even in increasing market share at the same time, kept high asset quality, profitability improved steadily. But, overall, joint stock commercial banks and state-owned commercial banks in business model, development, business structure, and the customer base, not profits, etc. Problems and difficulties for the development of shareholding commercial Banks have come to the attention of theory and practice, the Banks have also felt the pressure of facing in the process of development, to put forward the strategic transformation, and has carried on the beneficial exploration on the operation and management, and try, such as to the retail business transformation, risk management, credit approval, the company's business, audit management system adjustment, vigorously develop intermediary business, strengthen the financial innovation, etc.

From the external factors, economic development level, that financial system structure, financing institutional arrangement, corporate finance, financial market access barriers from institutional and environmental aspects such as indirectly affects the realization of the scale economy of commercial bank; From the internal factors, the level of the bank capital adequacy, liquidity, shareholder returns expectation directly decides the boundary radius and the expansion of bank scale expansion. Liquidity requirement is commercial bank scale expansion and key variables. Commercial Banks through the 
liabilities to assets expansion, the quantity and the duration of the liabilities structure determines the quantity and the duration of the asset structure, if not assets structure and liability structure period and number of matches, so, commercial banks liquidity risk will occur, and is the life of the commercial bank liquidity. Objectively, seek expansion more is the will and the requirement of bank management, and shareholders as the consignor is erosion may worry about their own interests, need to weigh the choice between the long-term interests and the short-term interests, and weigh the choice preference shareholders' return on investment is the important basis of time and good expectations for earnings.

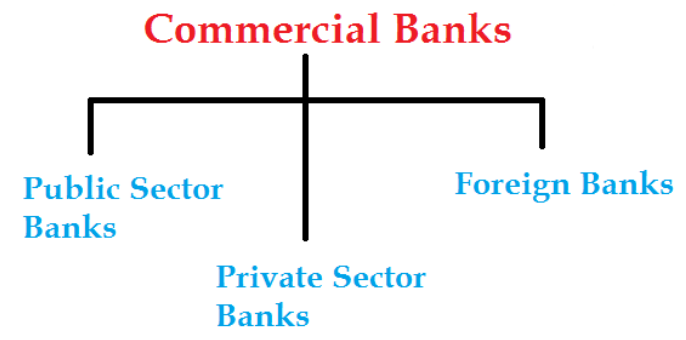

Fig. 2 The Components an Architecture of the Commercial Banks

Financial System Optimization. The practice of economic development shows that economic growth depends on three elements: one is the accumulation of elements, especially the accumulation of capital. The second is from low level to high level of industrial structure, third it is technological progress. Pattern, according to the configuration and utilization efficiency of social capital depends on the efficiency of the social resources flow and configuration and the efficiency of the social resources flow and configuration depends on the financial system configuration and efficiency of capital flows. In other words, the social efficiency of the financial system determines the efficiency of the capital allocation, determines the scale and efficiency of social capital accumulation [4-5].

In the financial system, occupied the main part of small and medium-sized financial institutions, and perfect the financial institutions, improve financial service quality, to enhance competitiveness of the financial system is essential for the development of small and medium-sized financial institutions.

- An important characteristic of small and medium-sized financial institutions is regional, it in enterprises in the region information has a great advantage, therefore, small and medium-sized financial institutions to take advantage of these services for small and medium enterprises should be advocated by local governments.

- The people's bank of China to perform the duties of the central bank more and that more professional, more focused on the formulation and implementation of monetary policy, more focus on the stability of the financial system, thus the independence of monetary policy has been enhanced. But, overall, independence of people's bank of China is yet to be improved.

- Small and medium-sized financial institutions to improve the internal management system, is put in operation and management problems to solve, legitimate business, in the construction of strengthening internal control mechanism, clear relationship between power and that the responsibility, and makes the management organization structure has been perfect, but also voluntarily accept supervision.

China Minsheng Bank Corp. As a testing ground for China's banking reform, China Minsheng banking born from that day on, is the product of the socialist market economy, it shoulders the historical mission of Chinese commercial banking reform pioneer.

Minsheng bank can make such progress, thanks to more than 30 years of reform and opening-up, especially since 1992, the socialist market economic system gradually establish and the basic perfect continuously, the marketization and commercialization for Minsheng bank provides external security. At the same time, as a private nature, Minsheng bank in 16 years continuous innovation and that exploration test, on the one hand, to realize its healthy and rapid development, on the other hand also for Chinese banking marketization, commercialization reform provides important experience for the reference. The characteristics of the Minsheng bamk could be generally summarized as the follows. (1) 
Build a comprehensive risk management system, effective risk prevention. At present, the global economic recovery is still a lot of uncertainty, China's economic system reform and that structural adjustments are more urgent task. In improving risk management organization system, on the basis of Minsheng bank project is steadily push forward new capital agreement, three quantitative risk management capacity economic returns on capital, economic capital management tools such as in product pricing. (2) To speed up the elaborating management change, all-round implementation of a series of engineering management ascension, increase management efficiency. After several years of exploration and improvement of division system advantage began to emerge, the next step is to adhere to the direction of company operation, continue to deepen reform of division and to consolidate and strengthen financial services in the field of industry, professional advantage. (3) Understanding the development and change of national policy and basic macroeconomic, strategic adjustment to build sustainable development ability. In 2008 the world economy after the financial crisis, the economic transformation and structural adjustment and financial deepening become the key to the development of our country's economy to continue.

\section{Summary and Conclusion}

This paper analyzes the challenges and related countermeasures on the development of the private commercial banks with example of China Minsheng bank corp. At present, the serious homogeneity competition, bank, both state-owned banks, joint-stock banks and city firms are by increasing shop outlets around the country, to expand the profit. In fact, since the interest rate marketization, more pressure and small and medium-sized Banks, it also put forward higher requirements on its own development model, want to rely on the traditional large profitable way or have not reality. Private capital into the financial sector needs the gradual process, that including private capital investment management ability that need to gradually improve. This paper proposes the novel perspective on the related issues that is meaningful and innovative.

\section{Acknowledgement}

This paper is financially supported by the humanities and social science in colleges and universities in Shandong province (NO. J15WG46). The project name is: research on issues and countermeasures of the private commercial banks during development.

\section{References}

[1] Biswakarma, Gangaram. "Organizational Career Growth and Employees ${ }^{e e}$ Turnover Intentions: An empirical evidence from Nepalese Private Commercial Banks." Human Resource Management 3.2 (2016): 10-26.

[2] Fernando, H. S. "Comparative Study on the Ownership, Financial Performance and Financial Efficiency of Private License Commercial Banks in Sri Lanka." (2015).

[3] Khanal, Suvash, and Bharat P. Bhatta. "Evaluating Efficiency of Personnel in Nepalese Commercial Banks: A Data Envelopment Analysis." Available at SSRN 2626082 (2015).

[4] Cornett, Marcia Millon, Otgontsetseg Erhemjamts, and Hassan Tehranian. "Corporate Social Responsibility and its Impact on Financial Performance: Investigation of US Commercial Banks." Department of Finance, Bentley University, Waltham Journal 1 (2014): 1-53.

[5] Merme, Vincent, Rhodante Ahlers, and Joyeeta Gupta. "Private equity, public affair: Hydropower financing in the Mekong Basin." Global Environmental Change 24 (2014): 20-29. 